\title{
Pelatihan Pengembangan Usaha Jamur Tiram Putih “Rumah Jamur Nando" di Pekanbaru
}

Hamdi Agustin ${ }^{1}$, Sri Indrastuti ${ }^{1}$

${ }^{1}$ Program Studi Manajemen, Fakultas Ekonomi dan Bisnis, Universitas Islam Riau, Jl. Kaharuddin Nasution No.113, Kota Pekanbaru, Propinsi Riau, Indonesia - 28284

*Penulis koresponden: hamdiagustin@eco.uir.ac.id

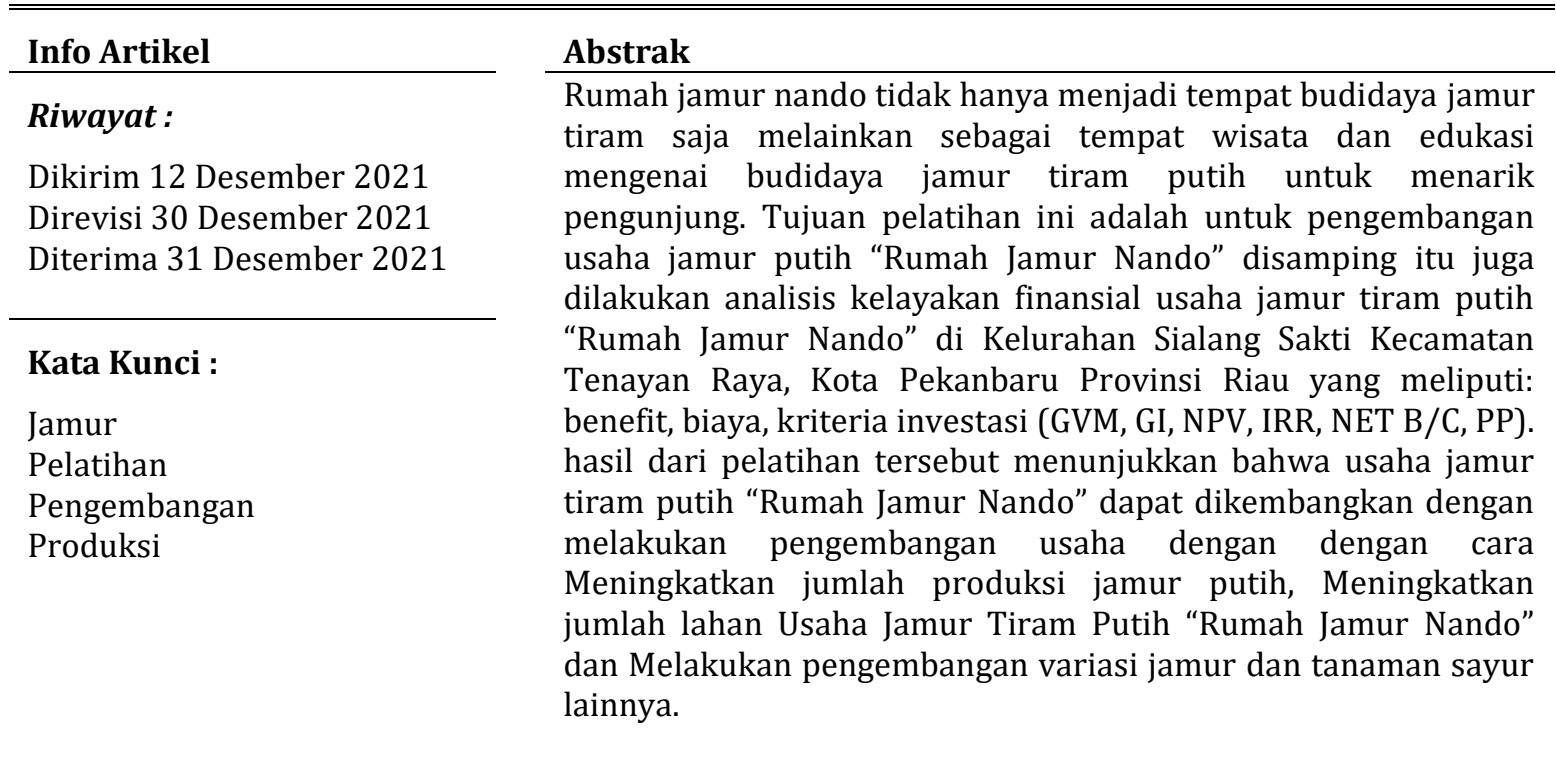

\section{PENDAHULUAN}

Salah satu daerah yang membudidayakan jamur tiram adalah Kota Pekanbaru dimana laju pertumbuhan penduduknya setiap tahun mengalami kenaikan sehingga permintaan jamur meningkat. Besarnya permintaan jamur tiram di Kota Pekanbaru perhari tidak diimbangi dengan besarnya produksi yang dihasilkan di daerah ini, bahkan produksi jamur tiram di Kota Pekanbaru berfluktuatif. Pada tahun 2016 produksi jamur tiram sebesar $20.306 \mathrm{~kg}$ dengan luas panen $80 \mathrm{~m}^{2}$. Pada tahun 2017 produksi jamur tiram turun drastis hanya sebesar $2.000 \mathrm{~kg}$ dengan luas panen $15 \mathrm{~m}^{2}$. Sedangkan pada tahun 2018 produksi meningkat drastis sebesar $72.849 \mathrm{~kg}$ dengan luas panen $25.042 \mathrm{~m}^{2}$. Dengan dimkian jumlah luas tanam, luas panen dan produksi dari tahun 2016 sampai 2018 mengalmi peningkatan. Produktivitas juga mengalami peningkatan dari tahun 2016 produktivitas jamur tiram di Kota Pekanbaru sebesar 253,83 kg/m², kemudian menurun menjadi 133,33 kg/m² sedangkan pada tahun 2018 meningkat menjadi 2,909 kg/m². Untuk lebih jelasnya dapat dilihat pada Tabel 1.

Tabel 1. Produksi Jamur Tiram di Kota Pekanbaru Tahun 2016-2018

\begin{tabular}{llllll}
\hline No & Tahun & Luas Tanam $\left(\mathrm{m}^{2}\right)$ & Luas Panen $\left(\mathrm{m}^{2}\right)$ & $\begin{array}{l}\text { Produksi } \\
(\mathrm{kg})\end{array}$ & Produktivitas $\left(\mathrm{kg} / \mathrm{m}^{2}\right)$ \\
\hline 1 & 2016 & 39.632 & 80 & 20.306 & 253,83 \\
2 & 2017 & 10.698 & 15 & 2.000 & 133,33 \\
3 & 2018 & 20.546 & 25.042 & 72.849 & 2,909 \\
\hline
\end{tabular}

Sumber: Dinas Tanaman Pangan dan Hortikultura, 2019

Salah satu kecamatan yang membudidayakan jamur tiram putih yaitu Kecamatan Tenayan Raya tepatnya di Kelurahan Sialang Sakti dengan nama usaha Rumah Jamur Nando. Rumah Jamur Nando merupakan tempat budidaya jamur tiram yang berdiri sejak tahun 2015 yang memiliki satu kumbung jamur dengan kapasitas 3.000 baglog. 


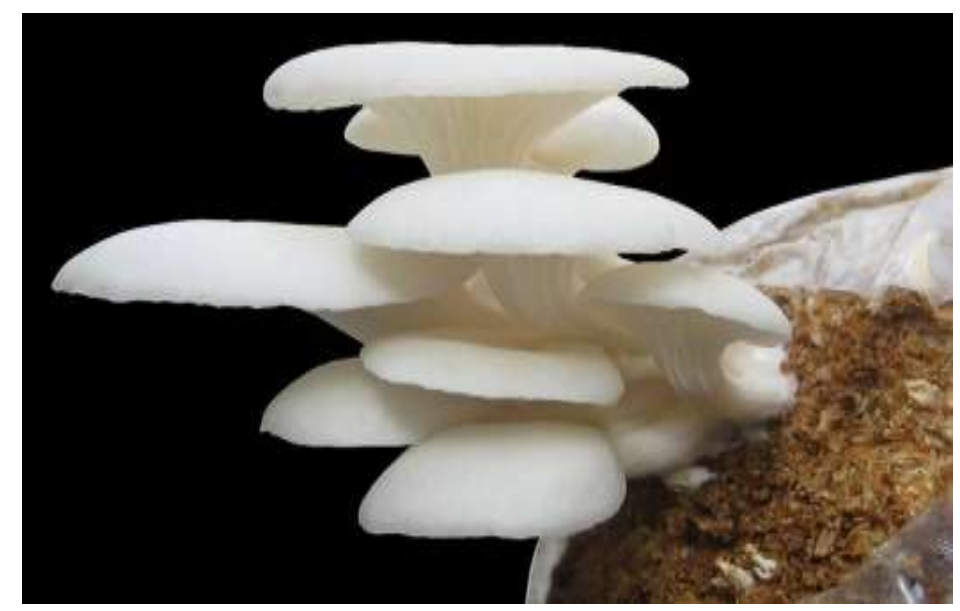

Gambar 1. Jamur Tiram Putih

Rumah jamur nando tidak hanya menjadi tempat budidaya jamur tiram saja melainkan sebagai tempat wisata dan edukasi mengenai budidaya jamur tiram putih untuk menarik pengunjung. Pengunjung yang datang ke Rumah Jamur Nando bisa mencapai 200 orang dalam satu minggu dan setiap pengunjung biasanya akan memesan dan membeli jamur tiram kurang lebih 1 kg per orang, dan permintaan jamur tiram juga berasal dari pasar tangor, outlet jamur crispy, café, dan restoran yang ada di sekitar wilayah kota Pekanbaru. Karena banyaknya permintaan yang datang untuk membeli jamur tiram, maka "Rumah Jamur Nando" menambah persediaan jamurnya dengan cara membeli dari para petani jamur yang ada di Provinsi Riau dan sekitarnya.

Usaha jamur tiram putih "Rumah Jamur Nando" masih memiliki kapasitas kumbung jamur tiram nya sekitar 3.000 baglog sehingga hanya bisa menghasilkan jamur tiram putih segar sebesar $1.200 \mathrm{~kg}$ per periode. Dengan demikian masih kekurangan dalam memenuhi permintaan jamur tiram putih yang berasal dari pengunjung wisata dan edukasi "Rumah Jamur Nando", pasar tangor, outlet jamur crispy, cafe, dan restoran adalah karena dalam usaha budidaya jamur tiram putih di "Rumah Jamur Nando" memerlukan biaya investasi yang besar diantaranya: bangunan, perlengkapan dan peralatan (ember, cangkul, ayakan, drum pengukusan, kompor, tabung gas, plastik, timbangan, keranjang panen, lilin, thermometer dan lainnya).

Di sisi lain, dalam mengembangkan usaha jamur tiram kedepannya pengusaha juga dihadapkan pada berbagai kemungkinan resiko yang akan dihadapi, diantaranya: masih rendahnya tingkat pendidikan tenaga kerja, minimnya pengalaman berusaha, adanya pengusaha lain yang menjadi pesaing, meningkatnya biaya operasional, turunnya produksi dan turunnya harga jual jamur tiram, sehingga akan berdampak pada penerimaan dan keuntungan yang diterima pengusaha "Rumah Jamur Nando" dimasa yang akan datang. Oleh karena itu, perlu dilakukan pelatihan pengembangan usaha jamur putih "Rumah Jamur Nando" di Kelurahan Sialang Sakti, Kecamatan Tenayan Raya, Kota Pekanbaru. Tujuan pelatihan ini adalah untuk pengembangan usaha jamur putih "Rumah Jamur Nando" disamping itu juga dilakukan analisis kelayakan finansial usaha jamur tiram putih "Rumah Jamur Nando" di Kelurahan Sialang Sakti Kecamatan Tenayan Raya, Kota Pekanbaru Provinsi Riau yang meliputi: benefit, biaya, kriteria investasi (GVM, GI, NPV, IRR, NET B/C, PP).

\section{TINJAUAN PUSTAKA}

Jamur merupakan organisme yang tidak berklorofil, sehingga jamur tidak dapat menyediakan makan sendiri dengan cara fotosintesis seperti pada tanaman berklorofil. Oleh karena itu jamur mengambil zat-zat makanan yang sudah jadi yang dihasilkan oleh organisme lain untuk kebutuhan hidupnya. Karena ketergantungan terhadap organisme lain inilah, maka jamur digolongkan sebagai tanaman heterofik. Ada beberapa jenis jamur tiram yang mulai banyak dibudidayakan antara lain sebagai berikut:

a) Jamur Tiram Putih (Pleurotus florida)

Jamur tiram putih, ditunjukkan pada Gambar 1, dikenal pula dengan nama shimeji white (varietas florida). Jamur tiram putih tumbuh membentuk rumpun dalam satu media serbuk gergaji kayu sengon (Albazia procera) dan kayu jeungling putih dengan kelembaban tinggi, warna tudungnya putih susu sampai putih kekuningan dengan garis tengah $3 \mathrm{~cm}-14 \mathrm{~cm}$. Setiap rumpun mempunyai 
Buletin Pembangunan Berkelanjutan

Vol. 5 No. 3, Desember 2021 hal. 13-20

percabangan yang banyak. Daya simpannya lebih lama dibandingkan dengan jamur tiram abu-abu, meskipun tudungnya lebih tipis dibandingkan dengan jamur tiram coklat dan jamur tiram abu-abu, tubuh jamur tiram putih relative lebih besar dan daging buahnya lebih tebal dibandingkan jamur merang.

b) Jamur Tiram Abu-Abu (Pleurotus sajor caju)

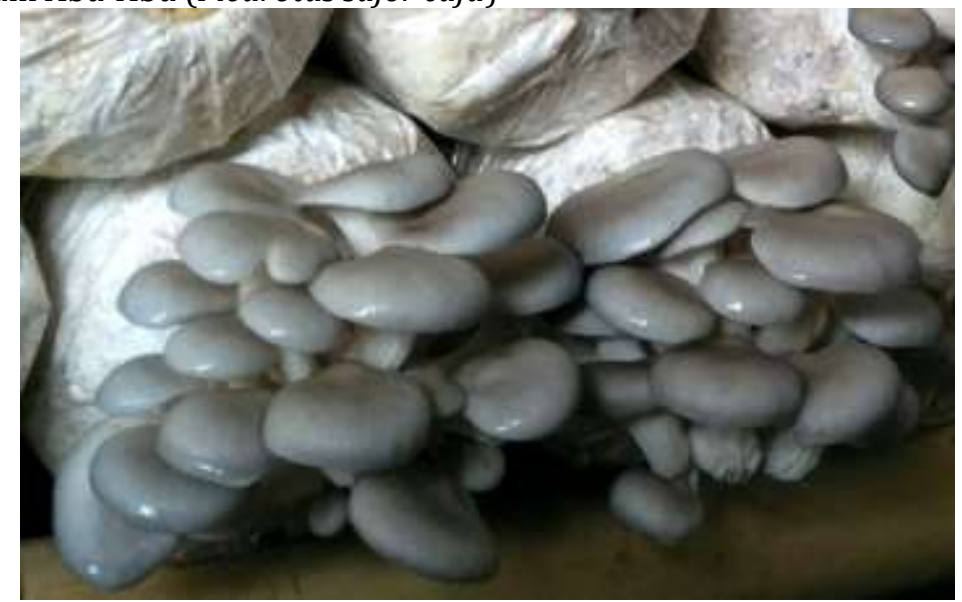

Gambar 2. Jamur Tiram Abu-Abu

Jamur tiram abu-abu dikenal pula dengan nama shimeji grey (varietas sajorcaju). Jamur tiram abu-abu (Gambar 2) mempunyai rumpun paling banyak dibandingkan dengan jamur tiram cokelat maupun jamur tiram putih, tetapi jumlah cabangnya sedikit dan lebih tipis dibandingkan dengan jamur tiram cokelat, dan warna tudungnya abu kecoklatan sampai kuning kehitaman dengan lebar $6 \mathrm{~cm}-14$ $\mathrm{cm}$, serta daya simpannya paling pendek.

c) Jamur Tiam Cokelat (Pleurotus cystidyosus)

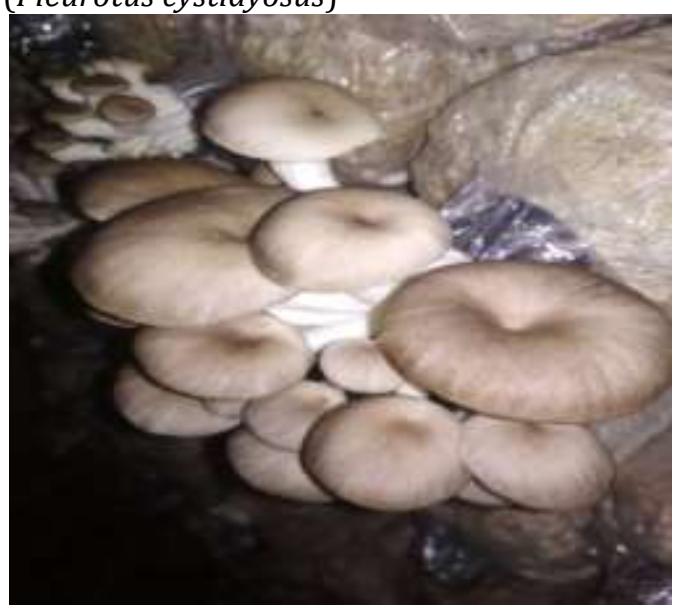

Gambar 3. Jamur Tiram Cokelat

Jamur tiram coklat dikenal dengan nama jamur abalone (varietas eystidiosus), warna tudungnya keputihan atau sedikit keabu-abuan sampai abu-abu kecoklatan dengan lebar $5 \mathrm{~cm}-12 \mathrm{~cm}$. Jamur tiram coklat, ditunjukkan oleh Gambar 3, mempunyai rumpun yang paling sedikit dibandingkan dengan jamur tiram putih dan jamur tiram abu-abu, tetapi tudungnya lebih tebal dan daya simpannya lebih lama.

d) Jamur Tiram Merah Atau Pink (Pleurotus Flabellatus) 


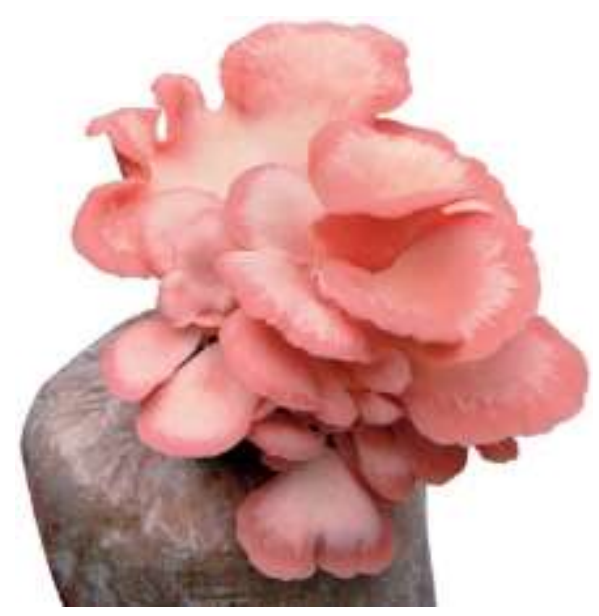

Gambar 4. Jamur Tiram Merah

Jamur tiram merah atau pink dikenal dengan nama shakura (varietas flabellatus), tudungnya berwarna kemerahan. Gambar 4 menunjukkan visualisasi dari jamur tiram merah.

e) Jamur Tiram Kuning (Pleurotus Citrinipileatus)

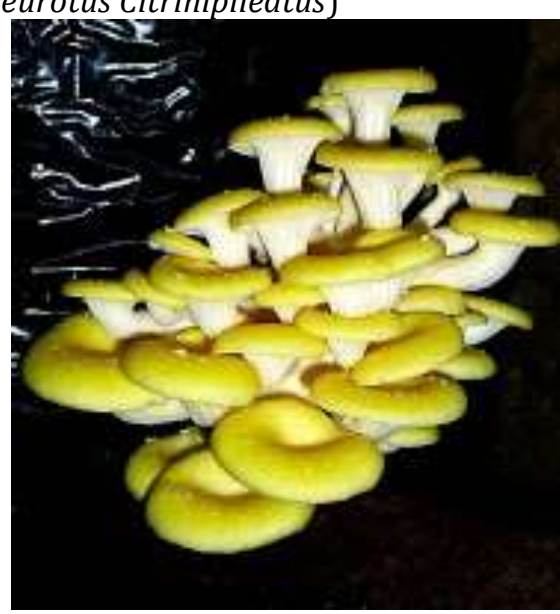

Gambar 5. Jamur Tiram Kuning

Jamur tiram kuning memiliki tudung berdiameter $2-5 \mathrm{~cm}$ berwarna kuning cerah bak emas sehingga dijuluki golden oyster alias jamur tiram emas. Gambar 5 menunjukkan bentuk jamur tiram kuning.

Untuk menilai kelayakan pengambangan usaha dapat dilakukan metode konvensional diataranya metode Net Present Value (NPV) dan Profitability Index (PI) dilakukan oleh Thirawat, et.al (2013), Suzan dan Aboul-Nasr (2013), Jusuf et.al. (2013), Victor dan Andreea (2014), Kusyanto (2014), Rizal et.al (2014), I Made P. (2015), kadek et.al. (2017) dan Mahirun dan Akhmad (2018). Sedangkan peneliti menilai investasi menggunakan metode Hamdi'S Method telah dilakukan oleh Hamdi. A. (2017), Ningsih (2018), Hamdi. dan Azwirman (2019), Hamdi et.al (2021) dan Ridho (2021). Diantara analisis yang digunakan adalah Gold Value Method (GVM) dan Gold Index (GI).

\section{METODE PELAKSANAAN}

Pelatihan ini dilakukan pada usaha jamur tiram putih di Rumah Jamur Nando. Lokasi Rumah Jamur Nando yaitu di Jalan Singkong, Gang Singkong No. 3 RT/RW 001/013, Kelurahan Sialang Sakti, Kecamatan Tenayan Raya, Kota Pekanbaru., Provinsi Riau. Penentuan lokasi tempat pelatihan ini dengan pertimbangan bahwa Rumah Jamur Nando adalah usaha jamur tiram putih sekaligus Wisata Edukasi Jamur pertama di Riau, namun belum pernah dilakukan penelitian tentang analisis kelayakan usaha jamur tiram putih. Penelitian ini dilakukan selama bulan November 2021.

Selain itu dalam pelatihan ini juga dipertimbangkan sebagai berikut: (1) Pelaku usaha merupakan ketua komunitas pengusaha dan petani jamur se-Riau yang memiliki 1 kumbung jamur 


\section{Buletin Pembangunan Berkelanjutan}

Vol. 5 No. 3, Desember 2021 hal. 13-20

dengan kapasitas 3000 baglog. (2) karyawan yang berjumlah 4 orang, dimana tugasnya yaitu mulai dari pembuatan media sampai dengan pasca panen jamur tiram putih. (3) Analisis kelayakan usaha jamur tiram putih di Rumah Jamur Nando belum pernah dilakukan sebelumnya. (4) Mengikutsertakan mahasiswa sebagai tambahan ilmu pengetahuan bagi mereka. Pelaksanaan Pengabdian ini ditunjukkan oleh Gambar 6 hingga Gambar 9.

\section{HASIL DAN PEMBAHASAN}

Kegiatan pelatihan tersebut dilakuan dengan cara ceramah dan diskusi dengan menyampaikan potensi usahan jamur putih pada saat ini. Dalam ceramah tersebut dipaparkan peluang-peluang pasar usaha jamur. Selain itu, juga dileaskan minat masyarakat dalam konsumsi jamur putih utuk dijadikan sayuran dalam menyajikan makan siang dan malam.

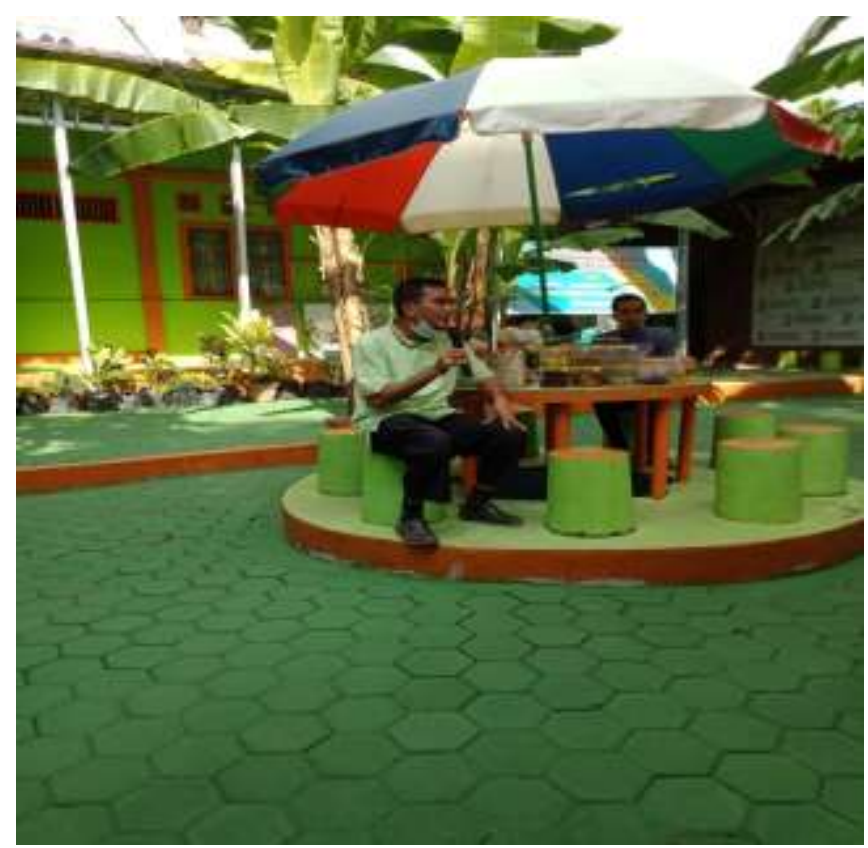

Gambar 6. Penyampaian Pelatihan Kepada Pemilik "Rumah Jamur Nando”

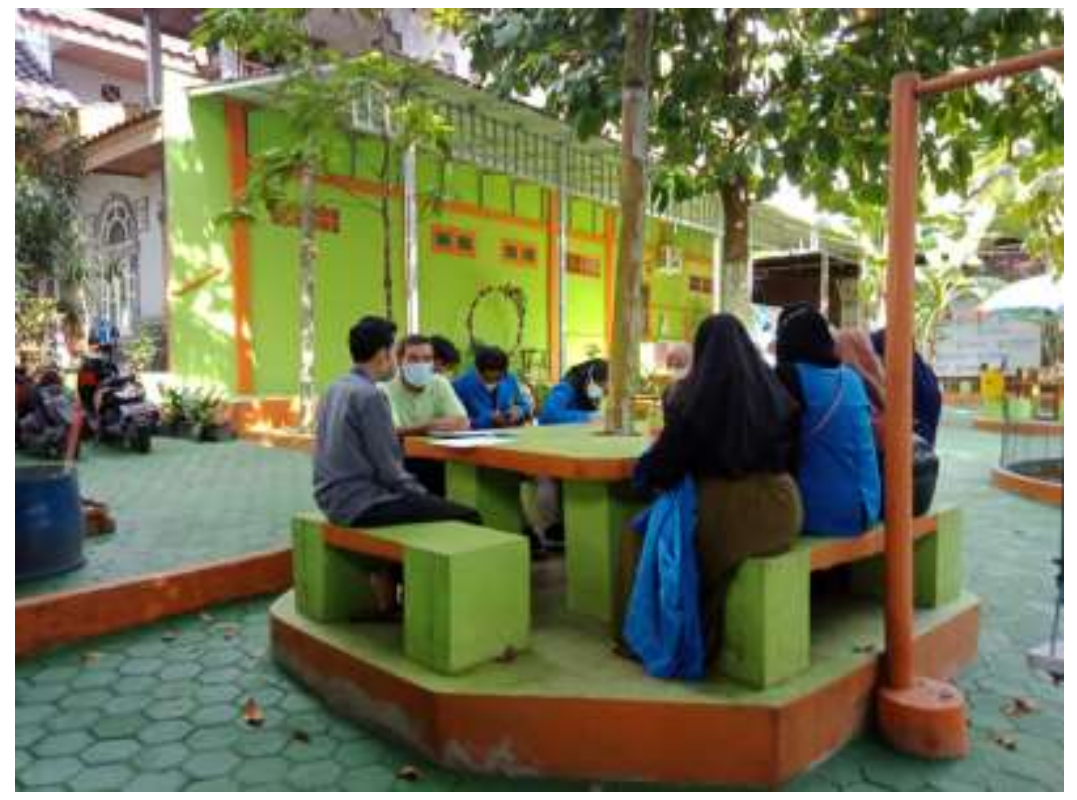

Gambar 7. Diskusi dengan Pemilik Usaha dan Mahasiswa 
Buletin Pembangunan Berkelanjutan

Vol. 5 No. 3, Desember 2021 hal. 13-20

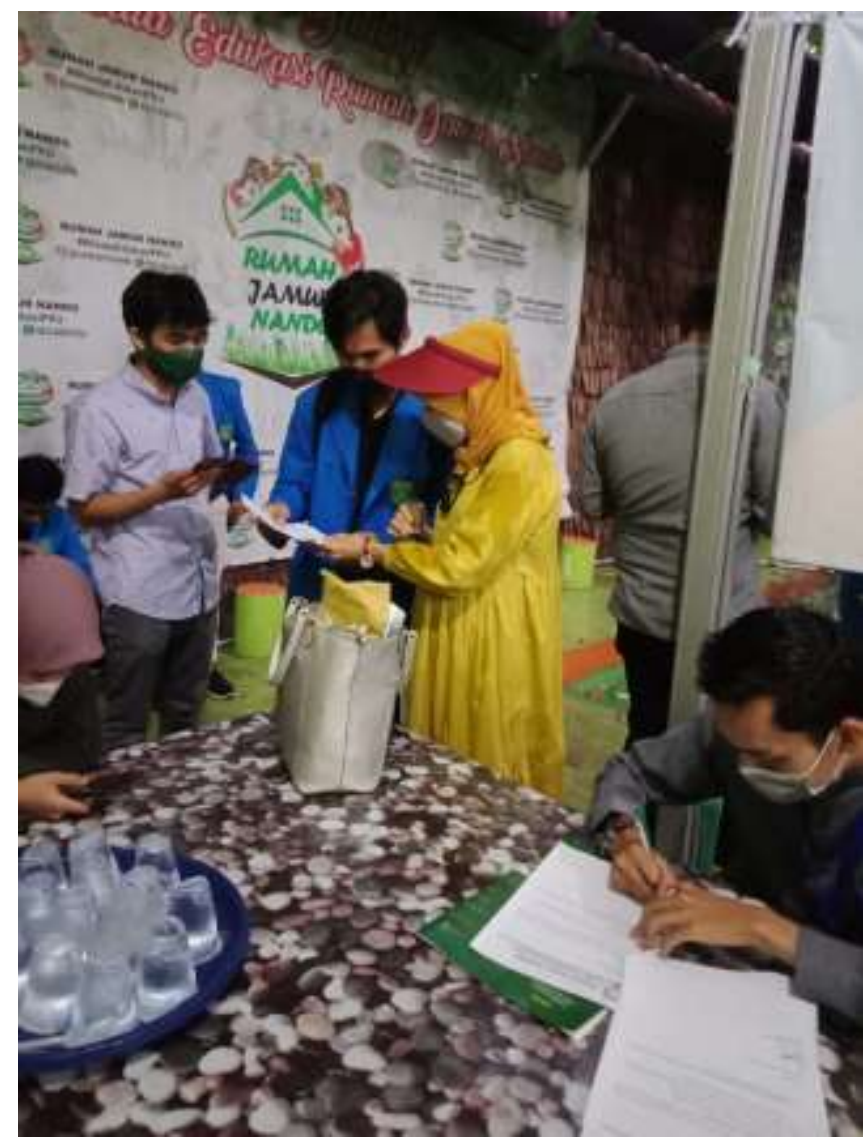

Gambar 8. Pelatihan ke Tempat Penanaman Jamur Putih

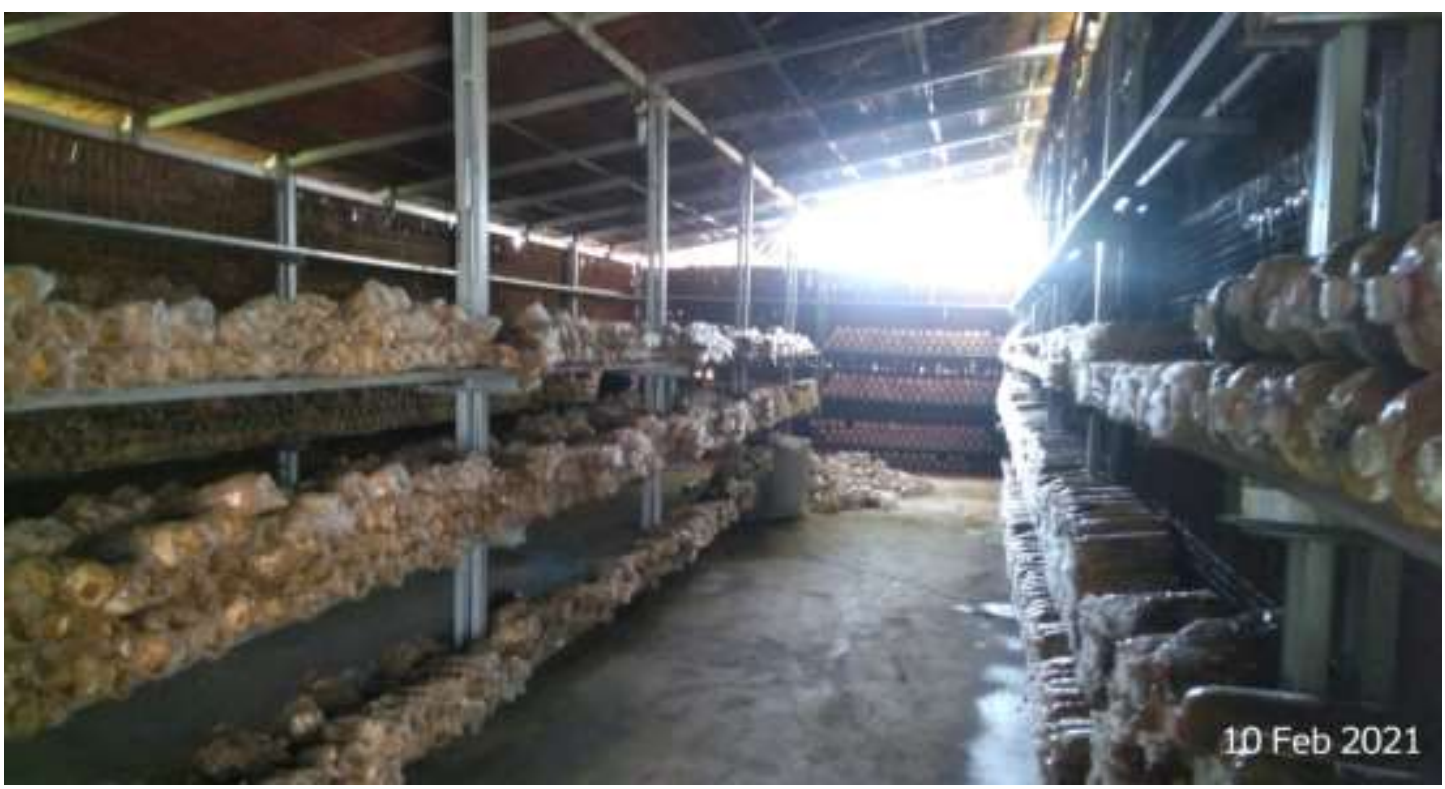

Gambar 9. Rumah Produksi Jamur Tiram Putih "Rumah Jamur Nando"

Dari hasil pelatihan dan wawancra menunjukkan hasil bahwa Usaha Jamur Tiram Putih "Rumah Jamur Nando" dapat melakukan pengembaan usahadengan dengan cara:

1. Meningkatkan jumlah produksi jamur putih. Karena permintaan jamur dari tahun ke tahun selalu meningkat sementara jumlah produksi jamur putih belum mampu untuk memenuhi permitaan konsumen. Dengan demikian Usaha Jamur Tiram Putih "Rumah Jamur Nando" 
dapat melakukan perluasan rumah produksi jamur agar dapat meningkatkan jumlah taman jamur putih. Hal ini dapat dilakukan dengan cara menambah rumah produksi untuk taman jamur putih seluas $75 \mathrm{M}^{2}$ sehingga dapat meningkatkan jumlah produk jamur untuk memenihi permintaan konsumen baik konsumen para wisatawan maupun konsumen untuk penjulaan di pasar dan rumah makan.

2. Meningkatkan jumlah lahan Usaha Jamur Tiram Putih "Rumah Jamur Nando". Hal ini dilakukan untuk meningkatkan kapasitas pengunjung yang akan menikmati agrowisata sehingga akan meningkatkan jumlah pembelian jamur putih. Strategi ini dapat dilakukan dengan membeli lahan kosong didepan dan dibelakang dari Usaha Jamur Tiram Putih "Rumah Jamur Nando" yang merupakan tanah kosong yang belum digunakan oleh pemilik tanah. Meskipun pada saat ini harga tanah tersebut dijual dengan harga yang relatif mahal.

3. Melakukan pengembangan variasi jamur dan tanaman sayur lainnya. Strategi ini dengan cara menambah budidaya tanaman sayuran selain jamur putih. Hal ini dilakukan untuk menambah jenis sayuran lain sehingga para pengunjung dapat menikmati edukasi tanaman sayuran lain seperti kangkung, cabai, tomat dan lain-lain.

\section{KESIMPULAN}

Dari hasil pelatihan yang dilakukan pada Usaha Jamur Tiram Putih "Rumah Jamur Nando" dapat suatu rekomendasi bahwa pengembangan usaha dengan dengan cara Meningkatkan jumlah produksi jamur putih, Meningkatkan jumlah lahan Usaha Jamur Tiram Putih "Rumah Jamur Nando" dan Melakukan pengembangan variasi jamur dan tanaman sayur lainnya. Saran usaha jamur tiram putih "Rumah Jamur Nando" lebih sensitiv pada penurunan produksi dengan demikian pengusaha harus mampu mempertahankan dan meningkatkan produksinya agar dapat mengembangkan lagi usahanya.

\section{DAFTAR PUSTAKA}

Hamdi A., Novita A., Armis dan Asril (2021). Analisis pengembangan usaha nenas sakinah berdasarkan aspek keuangan konvensional dan syariah (hamdi's method). Jurnal Tabarru' : Islamic Banking and Finance, (4)1, 219-230

Hamdi A. (2017). Analisis Keuangan Kelayakan Bisnis Syariah Hamdi's Model (Studi Kasus Usaha Swalayan Syariah di Pekanbaru). Jurnal Manajemen Bisnis Indonesia, 4(3), 295-305

Hamdi. A dan Azwirman (2019). The Analysis Feasibility Study on the Financial Aspects of Islamic Perspective Advances in Economics, Business and Management Research, 132, 69-73.

Hamdi.A (2017). Studi Kelayakan Bisnis Syariah. Jakarta: PT. Rajawali Press

I Made P. (2015). Analisis kelayakan investasi pasar tradisional desa Padangsambia di Denpasar Bali. Jurnal Teknik Sipil Untag Surabaya, 8(1), 79-94

Jusuf O. Panekenan, J.C. Loing, B. Rorimpandey dan P.O.V Waleleng. (2013). Analisis keuntungan usaha beternak puyuh di kecamatan Sonder kabupaten Minahasa. Jurnal Zootek ("Zootek" Journal),32(5), 1-10

Kadek S. I. G. B., Wiksuana, dan Luh G.R. (2017). Studi kelayakan pembangunan pusat Pembelanjaan Cokroaminoto. E-Jurnal Ekonomi dan Bisnis Universitas Udayana, 6(2), 789-818

Kasmir, \& Jakfar. (2009). Studi Kelayakan Bisnis. Jakarta: Kencana.

Khan, M. Akram. 1992a. Time Value of Money, dalam An Introduction to Islamic Finance Ch. 7 (Abod, Agil, danGhazali). Kuala Lumpur: Quill Publishers. 1992b. Capital Expenditure Analyisis in an Islamic Framework, dalam An Introduction to Islamic Finance Ch. 8 (Abod, Agil, danGhazali). Kuala Lumpur: Quill Publishers

Kusyanto. (2014). Analisis kelayakan ekonomi dan financial pendirian perusahaan daerah jasa pelaksana kontruksi di kabupaten Pemalang. Jurnal Eko-Regional, 9(2), 63-74.

Mahirun dan Akhmad, S. (2018). Studi kelayakan penyertaan modal kabupaten Pekalongan kepada pihak ketiga. Jurnal PENA, 32(1), 1-10

Ningsih (2018). Analisis Kelayakan Usaha Home Industri Roti Yanto Desa Kelapa Pati Kebupaten Bengkalis. Skripsi Program Studi Manajemen Fakultas Ekonomi Universitas Islam Riau 
Ridho, M. (2021). Analisis Kelayakan Pengembangan Usaha Laundry Sepatu "Schulogy Shoes Treatment" Di Jl. Lembaga Pemasyarakatan, Gobah Kota Pekanbaru. Skripsi Program Studi Manajemen Fakultas Ekonomi Universitas Islam Riau

Rizal Fathurohman, Abu Bakar dan Lisye Fitria. (2014). Analisis kelayakan usaha peternakan burung puyuh Di daerah Pasir Kawung Cileunyi kabupaten Bandung. Jurnal Online Institut Teknologi Nasional, 03(02),1-12

Suzan Abdelmajeed A., dan M. H. Aboul-Nasr (2013) Financial Feasibility Study of Bananas Tissue Culture Commercial Production in Egypt. Journal of Finance, Accounting and Management, 4 (2), 87-96.

Thirawat Chantuk, Teera Kulsawat dan Nawalak Klangburam (2013). Feasibility Analysis of Investment Project on Housing Development in Thailand with Valuation Technique based on Economy Factor. The Asian Conference on Society, Education, and Technology Official Conference Proceedings, Japan

Umar, Husein. 2007. Studi Kelayakan Bisnis. Edisi Ketiga. Cetakan Kesembilan. Jakarta: PT Gramedia Pustaka Utama.

Victor P. dan Andreea C. (2014), Monte Carlo Method in risk analysis for investment projects Procedia Economics and Finance 15, 393 - 400. 